\title{
Reduction in Practice: Tracing Husserl's Real-Life Accomplishment of Reduction as Evidenced by his Idea of Phenomenology Lectures
}

\author{
Dr. Juha Himanka, University Lecturer in Philosophy, University of Lapland, Finland \\ Email: juha.himanka@ulapland.fi
}

\begin{abstract}
Husserl claimed that reduction is the true starting point of phenomenological research, but to figure out how this deed should actually be accomplished has turned out to be a very challenging task. In this study, I explicate how Husserl accomplished reduction during his series of lectures entitled The Idea of Phenomenology. He does not state it explicitly, but what actually happened on the last day of the lectures can be seen as consistent with his descriptions of reduction as an act. Understood in this way, reduction is the model of how to do philosophy. The result of Husserl's reduction is the correlation between appearance and "that which appears" or, to use Husserl's later terminology, between noēsis and noēma. When this correlation is understood as an outcome of reduction and not as a result of an analysis, we, as readers of Husserl, will be in a better position to avoid natural attitude in our interpretations.
\end{abstract}

Keywords: reduction, phenomenology, experience, Husserl, noēma

\section{Introduction: Philosophising in the Original Sense}

As Husserl's reduction might, to the contemporary reader, seem like an alien way of doing philosophy, I will start from Plato's view of philosophising in order to show that Husserl's reduction is actually well in line with the original understanding of what philosophy is all about.

In Plato's Apology, Socrates recalls how his friend went to Delphi to ask the oracle whether there was anyone wiser than Socrates. The answer was that Socrates is the wisest because others only think they know but they do not. Socrates does not know either, but unlike the others - he is aware of his ignorance. This leads to a problem as far as teaching is concerned, and Socrates himself emphasised that he did not teach. He, however, did something that led to the learning of his followers.

In Plato's Meno, Socrates demonstrates to Meno how he helps a slave boy to learn without teaching him. The boy's task is to learn how to double the area of a square. At the beginning of the dialogue, the boy thinks that he knows the answer, but after Socrates' questioning he finally has to admit, "Indeed, Socrates, I do not know." After Socrates and Meno have considered that the boy's understanding of his own ignorance was actually beneficial to 
his learning, Socrates then guides the boy to find the right answer himself. It is rather easy to accept that in cases where prior knowledge is wrong, it prevents us from learning. We learn when we realise that our previous knowledge was incorrect, and we replace it with the correct facts. There is, however, also a more radical way of understanding the role of ignorance in philosophy, thinking and learning. We do not learn only by gaining new knowledge but also by letting go of what we already know, and this is a particularly important way of learning in philosophy.

In his book The Ignorant Schoolmaster, Jacques Rancière (1991) writes about the intellectual adventure of Joseph Jacotot. In 1818, Jacotot ended up teaching at the University of Leuven, Belgium. Jacotot was a Frenchman and could not understand Flemish, the local language. As most of his students could not understand French, there seemed to be a problem, but by using a bilingual copy of a book, he actually started to achieve very good learning results. The most important result was what Jacotot himself learned. He created an extraordinary view of teaching where the teacher should not have knowledge about what he or she is teaching. According to Jacotot, the teacher who knows ends up stultifying the students. What is remarkable is that Jacotot achieved very good learning results by using this method. I will not go into that method now; instead, I will examine how the views of Socrates/Plato and Jacotot/Rancière relate to each other.

Rancière states that Jacotot's way of teaching differs radically from the Socratic method and even sees the latter as a form of stultification (Rancière, 1991, p. 59). Rancière (1991) takes the slave boy episode from the Meno as an example:

Through his interrogations, Socrates leads Meno's slave to recognize the mathematical truth that lies within himself. This may be the path to learning, but it is in no way a path to emancipation. On the contrary, Socrates must take the slave by his hand so that the latter can find what is inside him. (p. 29)

Although Socrates does not tell the slave the right answer, he certainly knows it himself and can therefore guide the boy towards the solution. Rancière's/Jacotot's point is that Socrates is able to skilfully lead his students where he wants, and his not-knowing is therefore not radical enough. In my opinion, this critique is unfair as it does not consider who ultimately is the student on Plato's dialogues. Plato is aiming at the learning of his readers, and from that point of view, the texts are strikingly free from knowledge or doctrine.

In this study, I aim to show how Husserl's reduction follows the original Platonic way of doing philosophy. Phenomenology is not an approach to consider phenomena from the point of view of our previous knowledge of how to analyse and argue. Instead, it aims to open the correlation between appearance and that which appears (or noessis and noèma, to use Husserl's later terminology) without presupposing how we should arrange or analyse this correlation. Like Socrates, Husserl does not start with knowledge, but rather, for him, philosophising starts when we lose knowledge that we thought we had. The problem, then, is how are we to presuppose even the above-mentioned correlation between appearance and that which appears? My aim in what follows is to show how Husserl actually found this starting point on one particular day when he lost his knowledge base. In other words, I will describe how Husserl managed to accomplish something he calls reduction. 


\section{Husserl's Reduction}

Edmund Husserl was the founder of the philosophical movement called phenomenology. According to Husserl, the decisive factor of this way of doing philosophy is what he calls reduction, and it is reduction that resolves whether one follows the phenomenological method (HuaV76, 155; HuaIX/192; HuaXXVII/172; HuaXXIX/332; HuaDIII,4/83). It would be tempting to continue by asking what the concept of reduction means - how is it defined - but that would actually take us in the wrong direction. Reduction is not primarily a concept to be defined, but instead a deed to be done (Marx, 1987). We could compare it to eating: we can define what it means "to eat," but formulating a correct definition does not replace actually eating. It follows that accepting Husserl's view, reduction is the starting point of any phenomenological study, and it is actually an act we should make a distinction between: "philosophising about phenomenology" and "doing phenomenology" (Van Manen, 2014, p.23). Here I am interested in the latter: I am trying to elucidate Husserl's way of doing philosophy.

Reduction is a huge problem in Husserl research. Husserl emphasised its importance all the time (HuaV/76, 155; Hu IX/192; HuaXXVII/172), but based on his publications, it is not very clear what he means by it. During the 1930s, Husserl had an assistant called Eugen Fink. Husserl and Fink took daily walks and talked about philosophy, so the assistant had a perfect opportunity to find out how the phenomenological method works - or, in other words, how reduction is done (Cairns, 1976). Husserl, who was disappointed by how most of his followers understood the phenomenological method (HuaDIII/4, 85), finally saw that Fink was the only one who fully understood his approach (Müller, 1988; HuaDIII/4, 85; HuaXXVII/183, cf. HuaD III/4, 44). Could Fink help us to clear up what kind of a deed reduction is?

Unfortunately, according to Fink, the actual nature of reduction is nowhere to be found in Husserl's writings (Cairns, 1976, p. 15). This means that we have reached an impasse in our effort to understand how reduction should be done. I will, however, dare to challenge Fink's view and state that we can actually find Husserl's method of reduction in his writings. Before turning to that task, we need to have some understanding of what kind of a deed we are looking for.

We know that, according to Husserl, reduction is a philosophical method: it is a way to get philosophical results. Do we have any example of how Husserl achieved a philosophical result? In his essay about Husserl called In Memory of a Great Philosopher, Lev Shestov (1938) writes about his meeting with the founder of the phenomenological movement. Shestov had published a couple of articles critical of Husserl's philosophy, and the two philosophers happened to visit Amsterdam at the same time. To Shestov's surprise, Husserl was very eager to meet him. When the two men actually met, Husserl responded to Shestov's critique. He started by emphasising that his thinking does not form a stable set of results or knowledge. His thinking is more adventurous, and instead of adding new facts to what we already know, his work rather questioned whether we know at all:

The more deeply I probed into the basic problems of logic, the more I felt that our science, our knowledge, is shaking, tottering. And finally, to my own indescribable horror, I convinced myself that if contemporary philosophy has said the last word about the nature of knowledge, then we have no knowledge. (Shestov, 1938)

Here we are getting closer to our theme of losing knowledge as a source of philosophical insight. Husserl continues by explaining how he had reached the insight of his first major work, Logical Investigations: 
Once, when I was giving a lecture at the university, expounding ideas which I had taken over from our contemporaries, I suddenly felt that I had nothing to say, that I was standing before my students with empty hands and an empty soul. And then I resolved both for myself and for my students to submit the existing theories of knowledge to that severe and unrelenting criticism which has aroused the indignation of so many people. On the other hand, I began to seek the truth precisely where no one had sought it before, since no one had admitted that it might be found there. Such was the origin of my Logical Investigations. (Shestov, 1938)

Here we have Husserl's own description as remembered by Shestov of how he had reached a major result in his philosophical work, and this must mean that he had performed reduction. Could we find in Husserl's huge corpus something that relates to this? Although the timing does not match with the publication of Logical Investigations (1900-1901), the description itself fits very well with five lectures called The Idea of Phenomenology that Husserl gave in 1907. Although Husserl deals with the problem of knowledge quite often, it is here where the questioning of knowledge, in general, is the main theme.

\section{Love's Labour's Lost}

Husserl's vocabulary is rather narrow for a philosopher, but in The Idea of Phenomenology lectures, he uses two rare German words that both have their origins in literary works of art: Liebesmühe and Mahlstrom. The first refers to Shakespeare's play Love's Labour's Lost, and the second to Edgar Allan Poe's short story A Descent into the Maelstrom. In Shakespeare's play, some young noblemen try to dedicate themselves to their studies, but as romantic affairs keep disturbing them, they fail to do so. In Poe's story, two brothers fishing off the coast of Norway suffer a shipwreck as they accidently enter a horrible whirlpool called Moskenstraumen, the original Maelstrom. The narrator survives by observing what happens to the objects in the whirlpool and by using these observations to help himself escape.

In the first lecture, Husserl describes how we face problems and solve them with our normal, natural attitude, but when we then adopt a philosophical attitude and start to reflect on the relation between knowledge and its object, these problems change to "abysmal difficulties" (Abgrundtiefe Schwierigkeiten, 1986, pp. 18-19). In what follows, I will first discuss the passage where Husserl mentions Love's Labour's Lost (Husserl, 1999, p. 37) and his way of dealing with the problem and the solution. But like Shakespeare's protagonists, Husserl fails with his solution, and the original problem is transformed into abysmal difficulties. It is here that Husserl uses the word Maelstrom. The second model of reading, The Idea of Phenomenology, follows how Husserl's thinking adventure got him into this unforeseen Maelstrom, and this led to a learning experience that Husserl terms "reduction."

At the beginning of the lectures, Husserl sharply divides philosophy from science: "In comparison to all positive knowledge, philosophy ... lies in a new dimension; and to this new dimension there corresponds a fundamentally new method which is to be contrasted with the 'natural' method" (Husserl, 1991, p. 21). He then continues to explain how the way of knowing differs in philosophy and science by using the concepts of immanence and transcendence. The immanent is within one's consciousness (i.e., one's actual, real thoughts) and the transcendent is outside of it (e.g., that tree over there). In order to gain new knowledge, we need to establish a relationship between these two. Here we have two possibilities. On the one hand, we can start from the immanent - our actual thoughts - and therefore choose the philosophical or Cartesian 
option. On the other hand, we could start from the transcendent -- from the objective world without subjective influence -- and choose the scientific way of understanding knowledge. However, the problem in the situation is that when we start from either one of these options, we will, at the same time, sacrifice the other option. If we start from the objective, there seems to be no way to cover the subjective and vice versa. It follows that we do not know how knowledge is possible (Husserl, 1991, p. 30). Husserl continues by searching for a way out of this impasse and chooses to follow the Cartesian or philosophical option.

At the beginning of the third lecture, Husserl (year) states that he is about to examine the methodological essence of the reduction for the first time in concreto (p. 33). It is through reduction that the research is restricted to stay within the bounds of immanence (34, cf. note 17). But how are we to find a way from immanence to transcendence given that reduction has set the limit of staying within immanence? A couple of pages later, Husserl turns to this problem: "[I]t appears that we are faced with a circle that makes both phenomenology and epistemology impossible - and our love's labour [emphasis added] will, up this point, have been in vain" (Husserl, 1991, p. 37). However, it soon turns out that the problem is only an apparent one: "What we need here is a further step that will roll out this spurious circle for us. But we have actually already taken this step in principle [im Grunde] by distinguishing between senses of transcendence and immanence" (Hussserl, 1991, p. 37). Husserl gave an analysis of the two meanings of the immanence and transcendence in the second lecture before introducing reduction as a limitation to immanence in the third lecture. From the point of view of the phenomenological method, there is a problem in this way of proceeding. As Husserl explicitly points out, the decisive step is not reduction but the analysis of the concepts of immanence and transcendence that took place before the introduction of reduction. In the first attempt to solve the problem of knowledge that is presented using Love's Labour's Lost, the methodological tool is not reduction but analysis. I now turn to consider how this "solution" turned into the abysmal difficulty, the Maelstrom.

\section{Husserl's Descent into the Maelstrom}

In the fifth and final lecture, when the text is just about to reach the final solution to the problem of knowledge, the reader runs quite suddenly into a very strange diversion: "Only when we construct general judgments of essence do we attain the secure objectivity required by science [Wissenshaft]. So, we seem to have fallen into a Maelstrom" (Hussserl, 1991, p. 52). Reading the first sentence, one expects that Husserl is now reaching the goal of the lectures, but instead the text continues with the acknowledgement of a severe problem, the Maelstrom. The turn is so sudden that in the Husserliana edition, a sentence is added between these two claims to soften the contrast: "But nothing like that comes up here" (p. 52). Husserl has lost his way. The manuscript gives several possibilities to continue from here, and I choose to skip the two following paragraphs in which Husserl tries to find his way out by returning to the earlier themes of cogitatio and time. In the manuscript, these are marked for removal to an appendix. After this section, Husserl (1991) poses a set of questions starting with an acknowledgement of wonder - "But is this not a plain miracle?" (p. 52) - and continues with five questions about the limits of givenness. In the manuscript, one of the questions is underlined and sums up the line of questioning: "What is now the limit of the givenness?" (according to the original manuscript ${ }^{1}$ ). Husserl had suddenly realised that there was a problem with limiting his original

\footnotetext{
${ }^{1}$ I have studied the differences between the published lectures and the original manuscript in my earlier publications (Himanka 1999, 2011).
} 
starting point, and as the function of reduction was to limit, this is not a mere problem but an abysmal difficulty (Himanka, 1999.)

Earlier I cited Shestov's story in which Husserl talked about the sudden perplexity in front of his students that led him to find his original phenomenological insight. Here, in the fifth lecture, we find Husserl in a situation where we can image him standing "with empty hands and an empty soul" (Shestov, 1938) in front of his students. According to the story, Husserl resolved the situation and started to see truth in a new way. If the story tells about the events of the day of the fifth lecture, it follows that Husserl should have found a new way to perceive truth that evening. Is that what happened?

Husserl uses two different concepts - epoche and reduction - when he writes about reduction. In the ancient use of the word, epoche means the suspension of forming a judgment. In Husserl's usage, we understand it to mean the first phase of the whole reduction (HuaI/57; HuaVIII/165; Fink, 1986). If we compare it to the learning of the slave boy in Plato's Meno, the boy reaches epoche when he realises that contrary to his initial thoughts, he does not know the solution to the problem. Something similar happened to Husserl in the fifth lecture, and the solution he thought would work turned out to be a problem. Here Husserl has accomplished epoche: he has lost his knowledge base.

In order to complete the epoche into a reduction, we need to overcome the dead end and achieve a new insight. In the example of Meno, this happened when Socrates guided the boy to the right answer. Does Husserl manage to do the same in the lectures without a guide to help him? Does Husserl find his way out of the Maelstrom? It must have also occurred to Husserl that he had not finished the task during the lectures, and on the same day he had given the fifth lecture, he wrote The Train of Thought (Gedankengang) on the lectures (Hardy, 1999). The Train of Thought is not a mere summary of the lectures; it actually reflects on what happened to Husserl during the final lecture and goes significantly further than the lectures. Husserl completes the epoche of the fifth lecture into a reduction and presents a new insight that is the result of the learning he experienced that day.

\section{The Way out of the Maelstrom}

The Train of Thought of The Idea of Phenomenology lectures has a short introduction and steps $\mathrm{A}, \mathrm{B}$, and $\mathrm{C}$. The last lecture is a very difficult and confusing text to read, but here the thought proceeds firmly. I will first point out that it is in step C where Husserl reflects on how he got into the Maelstrom and then explains how he ended up with the new view, the idea of phenomenology.

We read earlier that after the Maelstrom, Husserl asked, "What is now the limit of givenness?" The question is underlined in the manuscript, and in the context of the lecture, this is a weighty question indeed (Himanka, 1999). Husserl first understood reduction as limiting the study to stay within the bounds of immanence, and now he suddenly understood he had lost those limits. In The Train of Thought, Husserl takes up this theme in step C by asking, "How far does self-givenness extend?" (p. 66) It is here that Husserl deals with the abysmal difficulty he calls the Maelstrom.

In English translation, step $\mathrm{C}$ is less than four pages long and there are two points that Husserl repeats several times within these pages. I take these points to be essential for Husserl in this situation: 1) Husserl repeats several times formulations like "first everything seemed quite straightforward" (p. 67) to us, but now we are "led further into the depths" (p. 67). For this reading, it is essential that Husserl does not write about others who have a naive view, but it is we - Husserl and his listeners - who during the lectures used to have too straightforward an understanding. In these formulations, Husserl reflects on how the Maelstrom led him to a 
deeper insight of the phenomenological method. 2) Even more striking, repetition in step C states, "the appearance and that which appears stand over against each other" (p. 67). Husserl mentions this insight five times in these couple of pages. When Husserl mentions this view a second time, he refers to it as something "new." As it is not new in the context of The Train of Thought, "new" here means that it is something new from the point of view of the lectures or in general. In what follows, I will refer to this newly found correlation as "the correlation."

Immediately after Husserl has ended up with the correlation for the first time, he writes, "we begin to wonder" (p. 67). When Husserl takes up the correlation for the fourth time, he writes about the "wonderful correlation" (p. 68). This gives us further evidence for the connection with the Maelstrom passage as the set of questions after it starts with "But is this not a plain miracle?" ( $p$ 52). This also connects Husserl's realisation with the classical view of starting to do philosophy. Both Plato (Plato, 1921, p. 155c-d) and Aristotle (Aristotle, 1933, p. 982b) saw that philosophy begins in wonder, and Husserl certainly knew and shared this view (HuaV/77; HuaVI/162, 168). Husserl was overcome by wonder when he realised the idea of phenomenology: the correlation. In his story to Shestov, Husserl tells that he started to search for truth in a new direction. In this study, I suggest that this new direction is the correlation.

As I noted above in step C, Husserl reflects repeatedly on "how different the seeing of things now proves to be" (p. 68). We know that what is new is the correlation, but what was the severe and unforeseen problem that Husserl faced? Husserl does not disagree with something he explicitly stated during the lectures; rather, it seems that he has implicitly presupposed something he now disagrees with. This presupposition was then revealed to him and what followed was the Maelstrom. Husserl mentions that the problem was the cogitationes, which were taken simply as given (p. 67). The problem of this Cartesian starting point is explained in step A of The Train of Thought.

Husserl describes the earlier point of view of understanding immanence in step A, and I read this to be also his own view during the actual lectures:

That the cognitive act can hit upon and find its mental object in the same [stream of] consciousness and with the same real here and now, that is what is taken for granted. The neophyte will say, at this pount, that immanent is in me, the transcendent outside of me. (Husserl, 1973, p. 3)

According to the naive model that Husserl himself also followed initially, we suppose that there is one point of time in which the relation between the inner and outer is constituted. It follows that nothing happens when the outer object turns into an inner representation or the inner "thought" finds its way to an outer object. In order for something to happen, there should be different phases of action and, for that, there must be more than one point of time. This way of limiting the study to one point of time does not open the relationship to study but instead closes it like in a case ("in einer Hülse oder einem Gefäß," Husserl, 1986, 12/ Husserl, 1999, 68) where the inner/outer transition is supposed to take place, but this change does not appear to us. When Husserl realised that this way of setting limits and closing the relationship in a case of the point of time does not work, he opened this restriction and started to wonder what the most primitive elements are when the something "constitutes itself" (p. 68). The reduction as presented in the third lecture rested on limiting the study to immanence, but in the last lecture, Husserl realised that the limiting factor, the one moment in time, does not work. This realisation initiated the real reduction of the lectures that ended up with the correlation as the genuinely reduced starting point of thinking.

This correlation between appearance (Erscheinung) and that which appears (Erscheinendes) is verbalised in many ways. Karl Mertens, for example, writes about "the inseparable relation of constituens and constitutum" (Mertens, 2018, p. 485). He also writes 
about the requirement of investigating the structures of both object and subject of experience and "to always considering them in correlation" (p. 472). This understanding of the correlation as a division between subjective and objective sides of phenomena explicates the correlation but, at the same time, fails to reach the real radicality of Husserl's idea. I will return to this at the end of this study. Dermot Moran, in turn, uses the terms cogitationes and cogitata to refer to the acts of the ego and its correlates (Moran, 2000). Here, Moran follows Husserl's own use of terms, but Husserl's latter choice of terminology, where appearance is called noessis and that which appears noema, seems more proper in the context of The Idea of Phenomenology. The Greek terms that refer to the times before the modern distinction between inner subject and outer world of objects might serve our purpose better.

From the perspective of reduction, this kind of reading means that Husserl wrote the actual lectures from the point of view of the natural attitude. The attitude then changed through reduction to the phenomenological one in The Train of Thought. The difference between these two texts explicates the difference between the natural and the phenomenological attitude. Since Husserl did not write only in the phenomenological attitude, we face a crucial problem of reading his texts. We should be able to distinguish between sections written in the natural attitude and those that are phenomenological; that is, we should be able to make a distinction between texts before and after reduction. In some occasions, Husserl mentions explicitly when he is trying to accomplish reduction, while in other texts, we can infer that from the change of terminology. However, as is the case when reading The Idea of Phenomenology, it requires very careful reading to see when reduction takes place (Himanka, 2011).

\section{Adventure of Thinking}

What happened to Husserl on the day of the last lecture, May 2, 1907, fits well with the description of reduction and with the story he told to Shestov. Husserl, however, does not himself seem to notice what he is doing: he does not mention that he therefore accomplished the reduction. Can we bypass this fact and state that Husserl performed reduction that day?

In My Way to Phenomenology, Martin Heidegger tells us how he became interested in Husserl's Logical Investigations, but his efforts to understand the work were in vain because he was not "searching the right way" (p. 75). He continued to work with the question of "how thinking's manner of procedure which called itself 'phenomenology' was to be carried out" ( $p$. 76) and finally started to understand how the method worked when he met Husserl in person.

A couple of years after he had met Husserl, Heidegger offered advice on how to relate to the works of Husserl in his lectures: "With Husserl's works we must make a difference between that what he has himself decided and defined purely terminologically and that what he has achieved in his real work" (Heidegger, 1972, p. 81). It is the latter - the actual work that really matters, and Heidegger emphasises this view firmly by first pointing out that without this distinction, Husserl's works will be misunderstood completely; he then also states that Husserl's self-interpretation is irrelevant [belanglos] (Heidegger, 1972). In this reading of The Idea of Phenomenology, I have followed Heidegger's advice and concentrated on what Husserl actually does in the lectures and The Train of Thought. From the "purely terminological" point of view, Husserl defines reduction as limiting the study to stay within immanence, but the reduction that led to the correlation is what "he achieved in his real work" (p. 81).

In addition to Heidegger, Husserl's assistants, Ludwig Langrebe and Eugen Fink, had an opportunity to follow Husserl's work closely. Both emphasise its adventurous nature (Fink, 1976; Landgrebe, 1963). I have emphasised that Husserl did not anticipate the problems of the fifth lecture, and according to Fink, reduction was essentially an unforeseen event (Fink, 1976). We can consider this aspect of Husserl's philosophising also from the perspective of the 
Aristotelian dichotomy between praxis and poiessis. From the Aristotelian perspective, we can understand Husserl's way of doing philosophy as a praxis. For Aristotle, praxis means doing whereby the result is essentially constituted in the making. When we, instead, follow the model of poiēsis, we, in one way or another, follow a model in our doing. The Idea of Phenomenology serves as an example of doing philosophy as a praxis.

Although I state that Husserl accomplished reduction on May 2, 1907, and the result was the idea of phenomenology, the correlation was not the one and only reduction Husserl performed. When we read the huge corpus of his working manuscripts, Husserl is all the time struggling to achieve reduction - sometimes he succeeds, sometime he does not. The power or curse ('der Bann', HuaVII/123-124; HuaXXVII/211, HuaXXIX/138; 220) of the natural attitude is so strong that it had to be overcome repeatedly. The accomplishment of reduction in these lectures is, however, particularly interesting, as it leads to the idea of phenomenology, the correlation.

\section{How does the Correlation Function?}

Before I turn to consider Husserl's adventure from the point of view of doing philosophy, I will briefly outline what Husserl's correlation means in practice. Husserl started his career as a philosopher of arithmetic. Number is that which appears, and it appears when we count: counting/number. In order to see the truth of numbers, we need to concentrate on this correlation between the number and its counting. In his book Numbers in Presence and Absence, Phillip Miller explicates how Husserl uses this method where the absent number (mere amount) comes into presence when we count (Miller, 1982). When we see some items on the table, there is an amount of items, but after we have counted them, there is a number of items. This was Husserl's original insight, and later on he started to consider whether the method could also have a wider use and named this attempt at a universal method - or strenge Wissenschaft - phenomenology. The reduction of The Idea of Phenomenology lectures shows how this approach is disintegrated from our natural way of dividing what appears to the inner sphere of our thought and the world outside.

Husserl's most controversial statement, that results from starting with the correlation, is to claim that the Earth does not move (Husserl, 1940). The study starts from the natural attitude, that is, from collecting together the view that we - including Husserl himself - are used to. He finds himself to understand the Earth as a body (die Körper) and names this point of view Copernican. Husserl then changes to the phenomenological attitude and considers the correlation. From the point of view of the correlation, a body is something that appears in a place and can either move or stay still. The Earth in its turn appears as a background to the possibilities of the movement and rest of a body. In order for the Earth to be a body there should be another Earth, an even more primordial background, in relation to which the Earth stays still or moves. Normally, we do not see a problem here and take the sun, ether, landscape of distant stars, or space-time to form such a background, but Husserl disagrees with this and states that there is only one Earth, and therefore it is not involved in either movement or rest (Himanka, 2000).

I will take another example of how the correlation functions from Heidegger. In the lecture series History of the Concept of Time, Heidegger explicates Husserl's method by using the nearby bridge as an example: "I can now envisage the Weidenhauser bridge; I place myself before it, as it were. Thus the bridge is itself given. I intend the bridge itself and not an image of it, no fantasy, but it itself." (Heidegger, 1985, p. 41) We would normally, within the natural attitude, think that when we envisage a bridge it certainly is not the bridge itself. The real bridge is somewhere out there and we are dealing with a representation of it and that is not the bridge 
itself. From the point of view of the correlation, however, Heidegger's statement makes perfect sense. When we envisage the bridge, it appears as we envisage it and that which appears is the envisaged bridge, the envisaged bridge itself. If we instead of the correlation envisaging/envisaged bridge consider the correlation between perception/perceived bridge, we then need to visit the bridge in order for it to be the bridge itself.

Heidegger's formulations like "language speaks" (die Sprache spricht) or "the world worlds" (die Welt weltet) might at first seem mysterious, but actually this kind of expressions are well in line with the correlation. Sentences just join together the two sides of the correlation, that which appears (language, world) and the appearing (speaking, worlding). This aspect of seeing the twofold nature of phenomenological evidence is on the one hand often neglected when one philosophises about phenomenology, but is on the other hand often used when one does phenomenology. I take a study of Kåre Fuglseth as an example of the latter (Fuglseth, 2012). In his phenomenological study about ignoring, Fuglseth writes that "we need to look at both the ignoring itself and the things-as-met or ignored-as-ignored" (Fuglseth, 2012). In this study, 'appearance' equals Fuglseth's 'ignoring itself' and 'that which appears' corresponds to 'things-as-met/ignored-as-ignored.'

\section{Reduction as a Way of Doing Philosophy}

Reduction for Husserl means that we need to distance ourselves from our accustomed understanding of the world - that is, we must distance ourselves from the natural attitude. In the case of the lectures, the essential character of the natural attitude was the division between immanence and transcendence. Husserl originally thought that it would be enough to rearrange this division, but to his surprise he finally had to reconstruct or even deconstruct the arrangement so significantly that it might have been more consistent to drop the concept of immanence altogether. The immanence/transcendence or inner self/outer world division is a strong model, and because of its historical roots and longevity, it seems very natural to us. Phillip Cary states that the inner self was invented by Augustine, but its origins reach even further back to Plato (Cary, 2000; cf. Schrader, 1995). It is very difficult to disengage oneself from this natural set-up of the inner self and the outside, but Husserl managed to do so and this opens up a way to understand truth or knowledge as the correlation between appearance and that which appears. When I manage to accomplish reduction and overcome the presuppositions of my natural attitude, this learning experience is not directed to new facts: rather, I actually educate myself.

Klaus Held understood reduction as the gradual overcoming of naivety (Held, 1966). By accomplishing reduction, we recognise our own presuppositions and become less naive. Husserl's Gedankengang explicates how this happened on one occasion, and as the title suggests, it actually explicates what happened in his thoughts. Thinking can be understood in many ways, but in philosophy there is a strong tradition of learning about ourselves when we think (Bormann et al., 1972).

In Plato's Meno, Socrates guided the boy to learn for himself. As we saw earlier, this is also the essential element of Rancière/Jacotot's ignorant teacher. In a way, this tradition culminated already in Descartes' method of doubt and the starting point of the cogito. Husserl understood Descartes to be the first to accomplish reduction (Hua13/150). Yet, it was indeed Cartesian tradition and the starting point of the cogito that led Husserl into an abysmal difficulty during the final lecture. Here it was the Cartesian tradition that formed the framework of the natural attitude to be overcome by reduction.

Reduction as a method of research is problematic. David Bell describes his distaste towards this kind of an approach: 
There is something dismal and dogmatic about philosophy whose utility, cogency and plausibility depend essentially, not on objective arguments, rational analysis or the critical consideration of evidence available to all, but rather on the individual philosopher's having undergone some esoteric experience. (Bell, 1990, p. 180; Moran, 2000, p. 161)

Bell's view is certainly reasonable, but if we do philosophy on the radical and original level as Husserl did, we should not presuppose what rational analysis and objective argumentations mean. If we already know that our aim is to present objective arguments, we have narrowed down our view of truth before we began our search. Rationality of our starting point does not shield us from the curse of the natural attitude, not even when we do Husserl research. In this radical version of Husserlian phenomenology that begins with reduction, truth is not the starting point but the end result (Mertens, 1996, p. 147). A study that refuses to take the rationalistic point of view for granted can lead to the truth as Husserl exemplified in The Idea of Phenomenology.

On what grounds could we rely on Husserl's learning experience as exemplified by the Idea of Phenomenology lectures? If we could find some scientific results to back Husserl up, might that help us? According to Husserl, however, philosophy lies in a dimension totally different from that of sciences, and thus, we must be able to do without scientific results. Furthermore, Husserl's own example does not encourage this kind of an approach as Husserliana is strikingly free from scientific results. Is it possible to do research without doing science? If not, there will be no room for phenomenological research.

Moran (2000) writes about working with reduction:

The reduction removed reliance on logic and mathematics. Even the law of noncontradiction cannot be assumed but must first be secured by evident insight. ... Intuitions must be clarified and reduced, and they then reveal new contents which were not available to ordinary consciousness and even ordinary reflection. Furthermore, they are 'verified' by others by those people carrying out the observations themselves. (p. 131)

I would replace the term 'observations' by 'reduction' and write about people or researchers accomplishing reduction themselves. To my knowledge, Husserl's reduction in the Idea of Phenomenology lectures is the most fully explicated description of experiencing reduction and the text is open for a careful reader to follow Husserl's path to his intellectual adventure. This is the evidence phenomenology can offer.

The difference between "before the reduction" (the actual lectures - natural attitude) and "after the reduction" (The Train of Thought - phenomenological attitude) seems to be only a nuance. Husserl himself often writes about the decisive nuance that makes the difference between succeeding and failing to reach for the truth (cf. HuaI/§14; HuaV/147; HuaXXIV/211). If we miss the reduction and the nuance that comes with it, we could just analyse the result Husserl got in The Train of Thought, that is, the correlation. We could explicate how we should investigate "the structures of both object and subject of experience" as I quoted above. This might help us to understand the division but, without reduction, this does not reach the full radicality of Husserl's idea. The correlation is the radically new beginning, and if we analyse it in relation to our earlier, natural ways of understanding, we lose the radicality of the idea and risk returning to the Cartesian point of view. We use our natural way of understanding truth as a relationship between our inner thoughts and the world outside us. And that is exactly the view Husserl managed to overcome in the reduction of the Idea of 
Phenomenology. I quoted Husserl above as he - after reduction - reflects his own position before reduction: "The immanence is in me, the beginner will say at this point, and the transcendence is outside me" (p. 63). Although Husserl often understood the beginner's perspective to be the philosophical view, here it refers to something he has managed to overcome.

Although the difference seems to be only a nuance, we should not confuse the views before and after reduction (Himanka, 2001). Reading Husserl from the point of view of reductions means that we do not try to relate Husserl's view into our own in order to understand it, but the reading instead dismantles or deconstructs our own presuppositions. This is well in line with Husserl's own instruction on how to read his texts.

In March 1930, Husserl wrote to Marvin Farber and gave him advice on how to relate to his work. He told Farber not to read his texts from the point of view of the result; Farber was supposed to struggle himself with the problems that the texts deal with (HuaDIII(4)/21-24). This is the only way to become a philosopher (HuaDIII(4)/21-24). Husserl's reduction aims at the kind of learning or study where one is responsible of overcoming one's own presuppositions oneself. It is not enough to read about Husserl's adventure of thinking; we should have the courage to struggle with our own presuppositions and to search for our own learning experiences or reductions in order to overcome them. The Idea of Phenomenology can, however, serve as an example of that kind of courage to think.

\section{References}

Aristotle. (1933). Metaphysics. London: William Heinemann. Retrieved from http://www.perseus.tufts.edu/hopper/

Bataille, G. (1988). Inner experience. Albany: State University of New York Press

Bell, D. (1990). Husserl: The arguments of the philosophers. London: Routledge.

Bormann, C., Kuhlen, R., \& Oeing-Hanhoff, L. (1972). Denken, in Historisches Wörterbuch der Philosophie. Band 2. Basel: Schwabe \& Co.

Cairns, D. (1973). My own life. In F. Kersten \& R. Zaner(Eds.), Phenomenology: Continuation and Criticis: Essays in memory of Dorion Carins (1-13). The Hague: Martinus Nijhoff.

Cairns, D. (1976). Conversations with Husserl and Fink. The Hague: Martinus Nijhoff.

Cary, P. (2000). Augustine's invention of the inner self. New York: Oxford University Press.

Fellman, F. (1989). Phänomenologie als ästhetische Theorie. Freiburg: Verlag Karl Alber.

Fink, E. (1976). Reflexionen zu Husserls phänomenologischer Reduktion. In Fink, Eugen, Nähe und Distanz (299-322). Freiburg: Verlag Karl Alber.

Fuglseth, K. (2012). Ignoring the child and the call for a good balance: Aspects of a phenomenologically based theory of teacher actions. Phenomenology \& Practice, 6(2), 84-93.

Hardy, L. (1999). Translator's introduction in Husserl, E: The idea of phenomenology. Dordrecht: Kluwer Academic Publishers.

Heidegger, M. (1972). My way to phenomenology. On Time and Being (74-82). New York: Harper \& Row.

Heidegger, M. (1985). History of the concept of time: Prolegomena. Bloomington: Indiana University Press.

Held, K. (1966). Lebendige Gegenwart, Die Frage nach der Seinsweise des tranzendentalen Ich bei Edmund Husserl, entwickelt am Leitfaden der Zeitproblematik. Den Haag: Martinus Nijhoff.

Himanka, J. (1999). Reductio in concreto: Two readings of the Idea of Phenomenology. Recherches husserliennes, 51-78. 
Himanka, J. (2000). Husserl's argumentation for the pre-copernican view of the earth. Review of Metahysics, 58(3), 621-644.

Himanka, J. (2001). Before and after Reduction: An interpretation of the initial distinction of Husserlian phenomenology. Journal of the British Society for Phenomenology, 32(2), 188-204.

Himanka, J. (2011). The idea of phenomenology: Reading Husserliana as reduction. Dialogue, Canadian Philosophical Association, 49(4), 617-640.

Husserl, E. (1940). Grundlegende Untersuchungen zum phänomenologische Ursprung der räumlichkeit der Natur. In M. Farber (Eds.), Philosophical Essays in Memory of Edmund Husserl. Cambridge: Harvard University Press.

Husserl, E. (1973). The idea of phenomenology. The Hague: Martinus Nijhoff.

Husserl, E. (1986). Die Idee der Phänomenologie. Hamburg: Felix Meiner Verlag.

Husserl, E. (1999). The idea of phenomenology. Dordrecht: Kluwer Academic Publishers.

Janssen, P. (1986). Einleitung. In Husserl E., Die Idee der Phänomenologie, IX-XLII.

Landgrebe, L. (1963). Husserls Abschied vom Cartesianismus. In L. Landgrebe, Der Weg der Phänomenologie, Das Problem einer ursprünglicher Erfahrung (133-177). Gütersloh: Gern Mohn.

Marx, W. (1987). Die Phänomenologie Edmund Husserls. München: W. Fink Verlag.

Mertens, K. (1996). Zwischen Letzbegründung und Skepsis, Kritische Untersuchungen zum Selbstverständnis der transzendentalen Phänomenologie Edmund Husserls. Freiburg: Karl Alber Verlag.

Mertens, K. (2018). Phenomenological Methodology. In D. Zahavi, D, The Oxford Handbook of the History of Phenomenology (469-491). Oxford: Oxford University Press.

Miller, P. (1982). Numbers in Presence and Absence: A Study of Husserl's Philosophy of Mathematics. The Hague: Springer.

Müller, M. (1988). Erinnerung. In H. R. Sepp (Ed.), Edmund Husserl und die phänomenologische Bewegung (30-41). Freiburg: Karl Alber.

Moran, D. (2000). Introduction to Phenomenology. Routledge: Abingdon.

Plato. (1903). Meno. Oxford University Press: Oxford. Retrieved from http://www.perseus.tufts.edu/

Plato. (1921). Theaetetus. William Heinemann: London. Retrieved from http://www.perseus.tufts.edu/

Rancière, J. (1991). The Ignorant Schoolmaster, Five Lessons in Intellectual Emancipation. Stanford University Press: Stanford, CA.

Schrader, W. H. (1995). Selbst. In Historisches Wörterbuch der Philosophie, Band 9. Schwabe \& Co: Basel.

Shestov, L. (1938). In Memory of a Great Philosopher. Retrieved from http://www.angelfire.com/nb/shestov/sar/husserl1.html

Van Manen, M. (2014). Phenomenology of Practice. Walnut Creek: Left Coast Press. 